\title{
IMBAL HASIL KONTRAK OPSI MENGGUNAKAN COVERED CALL WRITING STRATEGY DAN PROTECTIVE PUT BUYING STRATEGY
}

\author{
Atika Budiarti \\ atikabud@student.telkomuniversity.ac.id \\ Deannes Isynuwardhana \\ Hendratno \\ Fakultas Ekonomi dan Bisnis, Universitas Telkom
}

diterima: 31/3/2017; direvisi: 14/6/2017; diterbitkan: 27/4/2018

\begin{abstract}
This study aimed to analyze the return on contract option using covered call writing strategy and protective put buying strategy with black scholes. The population in this study are all companies listed in Indonesia Stock Exchange whose shares belong to the blue chip stocks. The sample in this research was determined by purposive sampling method to obtain 5 companies in the sample. Based on the results of the study, covered call writing strategy suffered losses, while the protective put buying strategy experiencing gains. The return of protective put buying strategy is better than the covered call writing strategy. For investors who want to invest in the derivatives market, particular contracts option investors should look at the movement of stock prices. If the movement of stocks tend to be stable, they should use the covered call writing strategy. If the stock tends to decrease, then they should use a protective put buying strategy.
\end{abstract}

Keywords: derrivative; contract option; covered call; protective put; black scholes

\begin{abstract}
Abstrak
Penelitian ini bertujuan untuk menganalisis imbal hasil kontrak opsi menggunakan covered call writing strategy dan protective put buying strategy dengan metode black scholes. Populasi dalam penelitian ini adalah seluruh perusahaan yang terdaftar di Bursa Efek Indonesia yang saham-sahamnya tergolong dalam saham blue chip. Sampel dalam penelitian ini ditentukan oleh metode purposive sampling sehingga diperoleh 5 perusahaan sebagai sampel. Berdasarkan hasil penelitian, covered call writing strategy mengalami kerugian, sedangkan protective put buying strategy mengalami keuntungan. Imbal hasil protective put buying strategy lebih baik daripada covered call writing strategy. Bagi investor yang ingin melakukan investasi di pasar derivatif, khususnya kontrak opsi sebaiknya investor melihat pergerakan saham. Jika pergerakan saham cenderung stabil, maka sebaiknya menggunakan covered call writing strategy, jika saham cenderung mengalami penurunan, maka sebaiknya menggunakan protective put buying strategy.
\end{abstract}

Kata Kunci : derivatif; kontrak opsi; covered call; protective put; black scholes 


\section{PENDAHULUAN}

Pasar modal merupakan salah satu alternatif sumber pembiayaan dan wahana investasi menjadi salah satu indikator ekonomi Indonesia. Perkembangan pasar modal Indonesia mengalami peningkatan kualitas maupun kuantitas. Faktor yang turut menentukan dalam pengembangan pasar modal adalah tersedianya instrumen investasi yang lebih variatif. Jenis-jenis instrumen investasi yang tersedia di pasar modal Indonesia saat ini adalah saham, obligasi, warran, bukti right, future, maupun reksadana. Disamping itu, untuk semakin menarik minat pemodal, instrumen investasi yang tersedia lebih divariasi, salah satunya dengan mengembangkan produk-produk derivatif.

Investasi tidak lepas dari adanya risiko. Investasi dengan tingkat pengembalian yang tinggi juga akan mendapatkan risiko yang tinggi. Risiko adalah tingkat potensi kerugian yang timbul karena perolehan hasil investasi yang diharapkan tidak sesuai dengan harapan, oleh karenanya para investor tersebut juga menjadi semakin peduli dengan risiko-risiko yang muncul dalam penanaman modalnya (Fahmi, 2012).

Risiko yang sering muncul dalam investasi adalah pengurangan nilai investasi saham. Risiko pengurangan nilai investasi saham dapat terjadi karena adanya pergerakan nilai saham yang tidak menentu. Pergerakan Indeks Harga Saham Gabungan tahun 2011-2015 ditunjukkan pada Gambar 1.

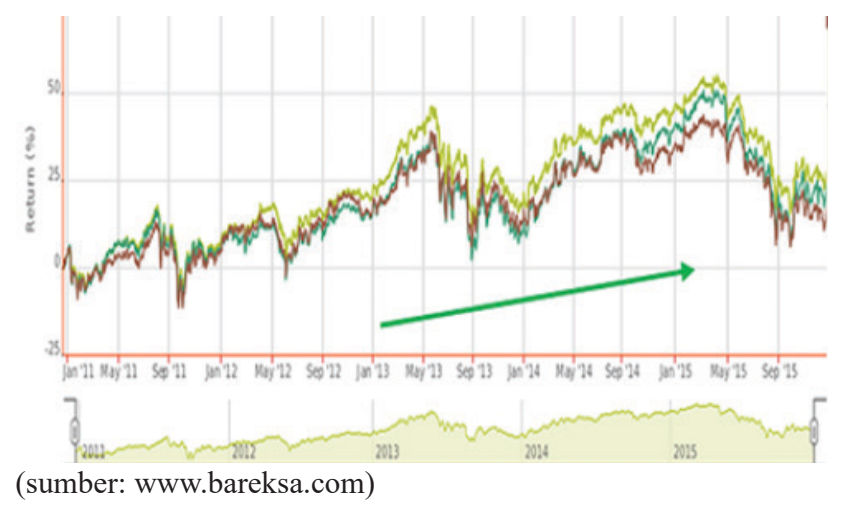

Gambar 1. Pergerakan IHSG Tahun 2011-2015

Gambar 1 menggambarkan risiko penurunan nilai investasi saham pada tahun 2011-2015. Dari gambar tersebut, terlihat bahwa terjadi fluktuasi terhadap harga saham dari tahun 2011-2015. Penurunan yang tajam terjadi sekitar bulan september 2011 dengan return $-12 \%$. Tahun berikutnya, yaitu bulan januari 2012 terjadi kenaikan sampai bulan april 2012. Penurunan terjadi lagi di bulan Mei 2012 dengan return 0\%. Bulan September 2012 sampai awal tahun 2013, harga saham relatif mengalami kenaikan. Bulan Mei 2013 sampai dengan bulan september, terjadi penurunan yang cukup signifikan dengan return mencapai $0 \%$. Pada bulan Januari 2014 kembali terjadi penurunan dengan tingkat return sekitar $10 \%$. Bulan berikutnya harga saham relatif terjadi kenaikan hingga bulan April. Pada bulan April sampai di titik dimana return mencapai 50\%. Bulan Mei sampai dengan September relatif terjadi penurunan harga saham.

Investor selalu meminimalisasi berbagai risiko yang timbul, baik risiko yang bersifat jangka panjang maupun risiko yang bersifat jangka pendek. Salah satu upaya untuk mengurangi risiko berkaitan dengan pengurangan nilai investasi saham yaitu dengan memanfaatkan produk-produk derivatif, seperti opsi. Dengan adanya opsi, investor dapat melindungi portofolio terhadap risiko penurunan harga pasar agar bisa memperoleh keuntungan yang lebih besar atau meminimalkan kerugian yang harus dihadapi (Hermuningsih, 2012).

Menurut Tandelilin (2010: 424) kontrak opsi saham terdapat beberapa strategi yang dapat digunakan dalam penilaian kontrak opsi. Pertama, naked strategy yaitu memilih salah satu posisi dari empat posisi yang bisa diambil pembeli call, penjual call, pembeli put, atau penjual put. Strategi naked tidak melakukan tindakan yang berlawanan atau mengambil posisi lain untuk mengurangi kerugian. Kedua, hedge strategy yaitu investor selain mengambil satu posisi dalam perdagangan opsi, ia juga mengambil posisi yang lain dalam perdagangan saham yang dijadikan patokan dalam opsi tersebut. Terdapat dua jenis hedge strategy, yaitu covered call writing strategy dan protective put buying strategy. Ketiga, straddle strategy dilakukan dengan cara membeli atau menjual, baik berupa call option maupun put option yang mempunyai patokan saham, expiration date, dan strike price yang sama. Terdapat dua jenis straddle strategy, yaitu long straddle dan short straddle. Keempat, combination strategy yaitu mengkombinasikan call dan put option dengan patokan saham yang sama, tetapi strike price dan expiration date berbeda. Kelima, spread strategy yaitu membeli satu seri dalam suatu jenis option dan secara simultan menjual seri lain dalam kelas option yang sama. Terdapat empat jenis spread, yaitu spread horizontal (spread waktu), spread vertical (spread harga), bull spread, dan bearish spread.

Penelitian sebelumnya terkait kontrak opsi saham, telah dilakukan oleh beberapa pihak. Penelitian yang dilakukan oleh Dewobroto, et. al. (2010) tentang strategi terbaik dalam hedging saham yang tercatat dalam Dow Jones Industrial Average (DJIA) Index. Strategi yang diteliti yaitu covered call, protective put, dan collar. Penelitian tersebut menyimpulkan bahwa strategi covered call merupakan strategi yang paling menguntungkan, dimana tingkat risikonya lebih rendah dibandingkan dengan strategi protective put. 
Namun demikian, tingkat pengembalian dari strategi protective put merupakan yang tertinggi dari ketiga strategi tersebut.

Penelitian yang dilakukan oleh Dash (2014) membandingkan strategi terbaik antara protective-put dan covered calls. Kesimpulan dari penelitian ini yaitu secara keseluruhan, protective put menghasilkan imbal hasil yang lebih baik dari covered calls. Dalam analisis yang lebih lanjut, strategi protective put akan optimal ketika saham yang distribusi pengembaliannya memiliki nilai rata-rata relatif lebih tinggi dan standar deviasi yang lebih rendah. Strategi covered calls akan optimal ketika saham yang distribusi pengembaliannya memiliki rata-rata relatif lebih rendah dan standar deviasi yang lebih tinggi.

Penelitian yang dilakukan oleh Adam dan Maurer (1999) yang mempelajari risiko, imbal hasil, dan profil dari beberapa strategi opsi saham. Penelitian ini menghasilkan kesimpulan yaitu bahwa di pasar keuangan yang efisien tidak ada strategi yang optimal untuk semua investor.

Penelitian yang dilakukan oleh El-Hassan, Hall, dan Kobarg (2004) menyimpulkan bahwa covered call strategies mengakibatkan laba rata-rata meningkat, standar deviasi yang lebih rendah, skewness lebih negatif dan risiko yang peningkatannya disesuaikan untuk portofolio yang seimbang.

Penelitian yang dilakukan oleh Sarmiadi dan Trinanto (2007) menyimpulkan bahwa terdapat beberapa faktor yang mempengaruhi opsi call dan opsi put, yaitu harga saham, harga exercise, tingkat bunga, jangka waktu jatuh tempo, dan volatility harga saham. Penentuan nilai opsi bisa dilakukan menggunakan model binomial (BPOM) atau rumus black scholes. Penelitian yang dilakukan oleh Guestyana dan Dewi (2014) menyimpulkan bahwa metode black scholes lebih akurat dibandingkan dengan metode monte carlo simulation.

Penulis akan menganalisis imbal hasil kontrak opsi dengan strategi covered call dan protective put, karena merupakan strategi dasar yang bertujuan untuk memproteksi investasi dari kerugian baik dari segi saham maupun option. Strategi tersebut juga digunakan untuk mengimbangi setiap pergerakan harga yang tidak diinginkan melalui perolehan keuntungan dari posisi lainnya (Sutedi, 2012). Penulis tertarik untuk meneliti lebih dalam instrumen derivatif, yaitu kontrak opsi saham. Penelitian ini akan menganalisis imbal hasil simulasi kontrak opsi dalam jangka waktu 1,2 , dan 3 bulan pada tahun 2015, karena menurut data yang diperoleh dari BEI, jangka waktu kontrak opsi yang ada di Indonesia maksimal 3 bulan.

Tujuan penelitian ini yaitu: (a) Untuk mengetahui imbal hasil investasi pada kontrak opsi saham menggunakan covered call writing strategy dengan masa berlaku 1 bulan, 2 bulan, dan 3 bulan pada tahun 2015; (b) Untuk mengetahui imbal hasil investasi pada kontrak opsi saham menggunakan protective put buying strategy dengan masa berlaku 1 bulan, 2 bulan, dan 3 bulan pada tahun 2015; (c) Untuk mengetahui strategi terbaik pada kontrak opsi saham, yaitu antara covered call writing strategy dan protective put buying strategy dengan masa berlaku 1 bulan, 2 bulan, 3 bulan pada tahun 2015.

Penelitian ini akan membahas mengenai imbal hasil kontrak opsi saham menggunakan strategi covered call dan strategi protective put dengan metode black scholes. Kontrak opsi berawal dari adanya investasi. Menurut Tandelilin (2010:1), investasi dapat diartikan sebagai komitmen untuk menanamkan sejumlah dana pada saat ini dengan tujuan memperoleh keuntungan di masa datang. Beberapa investasi berkaitan dengan aset finansial seperti deposito, saham, obligasi, dan surat berharga lainnya.

Investasi sangat erat dengan adanya risiko. Risiko tersebut dapat memungkinkan investor mengalami kerugian atas investasi yang dilakukan. Hasil investasi terkadang tidak sesuai dengan harapan investor. Risiko tersebut dapat diantisipasi dengan adanya instumen derivatif. Menurut Sutedi (2012:2), derivatif secara umum dapat didefinisikan sebagai instrumen keuangan yang nilainya diturunkan atau didasarkan pada nilai dari aktiva, instrumen, atau komoditas yang lain.

Jenis derivatif yang fungsinya mengurangi risiko pengurangan nilai yaitu opsi. Investor dapat menggunakan opsi untuk melindungi portofolio terhadap risiko penurunan nilai agar bisa memperoleh keuntungan yang lebih besar atau meminimalkan kerugian yang harus dihadapi. Menurut Sutedi (2012:47) pada dasarnya kontrak opsi adalah suatu opsi (suatu hak, dan bukan kewajiban) untuk menjual (put) atau membeli (call) suatu benda berwujud (tangible assets) ataupun benda tak bergerak (intangible assets) yang diberikan dengan imbalan tertentu umumnya dalam bentuk pembayaran premi. Dalam pelaksanaan kontrak opsi, akan ditentukan nilai/harga opsi tersebut dengan menggunakan perhitungan black scholes, berdasarkan nilai pada harga saham perusahaan.

Investor dapat menggunakan strategi perdagangan hedge, yang terdiri dari covered call writing strategy dan protective put buying strategy. Strategi tersebut digunakan untuk mengimbangi setiap pergerakan harga yang tidak diinginkan melalui perolehan keuntungan dari posisi lainnya. Penentuan imbal hasil dari kontrak opsi yaitu dengan menggunakan strategi tersebut.

Kontrak opsi dilakukan dalam jangka waktu maksimal 3 (tiga) bulan. Penelitian ini akan membandingkan dari jangka waktu 1 (satu) bulan, 2 (dua) bulan, dan 3 (tiga) bulan. Dari ketiga jangka waktu tersebut akan diketahui jangka waktu yang paling baik ketika melakukan kontrak opsi saham. Semakin lama waktu kontrak opsi dilakukan, tingkat risiko yang akan dihadapi juga semakin tinggi. Bagan kerangka pemikiran ditunjukkan pada Gambar 2. 


\section{METODE}

Variabel-variabel dalam penelitian ini meliputi harga call option, harga put option, dan imbal hasil. Operasionalisasi variabel ditunjukkan pada Tabel 1. Populasi dalam penelitian ini yaitu perusahaan yang sahamnya tergolong dalam saham blue chip yaitu sejumlah 45 perusahaan.

Teknik pengambilan sampel yaitu sampling purposive dengan kriteria yaitu saham perusahaan yang telah tercatat menjadi saham induk untuk perdagangan kontrak opsi saham di BEI (Tabel 2).

Tabel 2. Kriteria Sampel Penelitian

\begin{tabular}{lc}
\hline \multicolumn{1}{c}{ Kriteria } & $\begin{array}{c}\text { Jumlah } \\
\text { Perusahaan }\end{array}$ \\
\hline Saham perusahaan tergolong blue chip 2016 & 45 \\
Saham tidak tercatat menjadi saham induk & $(40)$ \\
Saham yang memenuhi kriteria dan menjadi & 5 \\
sampel penelitian & \\
\hline
\end{tabular}

Saham perusahaan yang memenuhi kriteria ditunjukkan pada Tabel 3.

Tabel 3. Sampel Penelitian

\begin{tabular}{lll}
\hline No & Nama Perusahaan & Jenis Saham \\
\hline 1 & PT Astra International Tbk & ASII \\
2 & PT Bank Central Asia Tbk & BBCA \\
3 & PT Indofood Sukses Makmur Tbk & INDF \\
4 & PT Telekomunikasi Indonesia Tbk & TLKM \\
5 & PT HM Sampoerna Tbk & HMSP \\
\hline
\end{tabular}

Sumber: www.pasarmodalpedia.com, 2015

Data sampel sejumlah 360 dengan penjabaran ditunjukkan pada Tabel 4.

Tabel 4. Data Sampel Penelitian

\begin{tabular}{|c|c|c|c|}
\hline \multirow{2}{*}{$\begin{array}{l}\text { Jangka } \\
\text { waktu }\end{array}$} & \multirow[b]{2}{*}{ Perhitungan } & \multicolumn{2}{|c|}{ Metode } \\
\hline & & $\begin{array}{l}\text { Covered } \\
\text { Call }\end{array}$ & $\begin{array}{c}\text { Protective } \\
\text { Put }\end{array}$ \\
\hline 1 bulan & $\begin{array}{c}12 \text { titik sampel x } 5 \text { sampel } \\
\text { perusahaan }\end{array}$ & 60 & 60 \\
\hline 2 bulan & $\begin{array}{l}12 \text { titik sampel x } 5 \text { sampel } \\
\text { perusahaan }\end{array}$ & 60 & 60 \\
\hline 3 bulan & $\begin{array}{l}12 \text { titik sampel x } 5 \text { sampel } \\
\text { perusahaan }\end{array}$ & 60 & 60 \\
\hline \multicolumn{2}{|c|}{ Jumlah data } & 180 & 180 \\
\hline \multicolumn{2}{|c|}{ Jumlah data sampel } & & 360 \\
\hline
\end{tabular}

\section{HASIL DAN PEMBAHASAN}

Hasil perhitungan terlihat bahwa harga opsi call dengan jangka waktu yang lebih lama akan lebih besar nilainya. Hal ini sesuai dengan salah satu karakteristik opsi dimana semakin lama jangka waktu kontrak opsi maka harga premi juga semakin besar. Dari hasil tersebut, diketahui bahwa besarnya harga premi dengan jangka waktu 2 bulan bukan berarti kelipatan 2 dari harga premi dengan jangka waktu 1 bulan. Sama halnya dengan harga premi dengan jatuh tempo 3 bulan, bukan berarti kelipatan 3 dari harga premi dengan jangka waktu 1 bulan. Sama halnya dengan harga opsi put, menunjukkan bahwa nilai premi put mengalami perbedaan antara jatuh tempo 1, 2, dan 3 bulan. Akan tetapi, semakin lama waktu jatuh tempo kontak opsi, premi put semakin menurun.

Hasil statistik deskriptif setiap variabel operasional ditunjukkan pada Tabel 5 dan 6. Kelima harga saham mengalami kerugian menggunakan strategi covered call writing dengan jatuh tempo 1 bulan, 2 bulan, maupun 3 bulan. Imbal hasil yang terjadi tersebut disebabkan oleh selisih harga yang tidak bisa tertutupi oleh premi yang diterima. Hasil tersebut menunjukkan bahwa penggunaan strategi covered call writing tidak tepat digunakan karena dari kelima jenis saham tersebut mengalami kerugian.

Berdasarkan hasil analisis tersebut, kelima saham mengalami imbal hasil keuntungan menggunakan strategi protective put buying dengan jatuh tempo 1 bulan, 2 bulan, dan 3 bulan. Meskipun di awal investor telah membayar premi, akan tetapi keuntungan yang diterima ketika investor mengeksekusi nilainya lebih tinggi dari premi yang dibayarkan, sehingga investor tetap mengalami keuntungan.

Berdasarkan hasil analisis tersebut, dapat dilihat bahwa strategi covered call writing lebih baik digunakan pada saat harga saham cenderung mengalami penurunan. Dari kelima saham tersebut diketahui bahwa imbal hasil dalam strategi covered call writing mengalami kerugian. Berbeda dengan strategi covered call writing, strategi protective put buying memberikan imbal hasil yang positif atau menguntungkan.

Dari analisis tersebut diketahui bahwa strategi protective put buying lebih baik digunakan saat ini dari pada strategi covered call writing. Hal ini terlihat dari imbal hasil yang terjadi dimana strategi protective put buying memberikan keuntungan sedangkan strategi covered call writing memberikan kerugian.

Pada strategi protective put buying yang paling menguntungkan dalam jangka waktu 1 bulan yaitu HMSP dengan rata-rata keuntungan 1.206,7973. Untuk jangka waktu 2 bulan yaitu HMSP dengan rata-rata keuntungan 544,6065. Sedangkan untuk jangka waktu 3 bulan yaitu ASII dengan rata-rata keuntungan 435,2837.

\section{KESIMPULAN}

Imbal hasil kontrak opsi menggunakan metode covered call writing strategy dengan jatuh tempo 1 bulan, 2 bulan, dan 3 bulan mengalami kerugian yang terjadi karena harga saham yang cenderung mengalami 
penurunan saat jatuh tempo kontrak opsi, sehingga harapan tidak sesuai dengan kenyataan yang terjadi. Selain itu, premi yang diterima di awal kontrak tidak bisa menutupi selisih harga yang terjadi saat kontrak opsi dieksekusi pembeli opsi.

Imbal hasil kontrak opsi menggunakan metode protective put buying strategy dengan jatuh tempo 1 bulan, 2 bulan, dan 3 bulan mengalami keuntungan, yang terjadi karena harga saham cenderung mengalami penurunan saat jatuh tempo kontrak opsi, sehingga harapan sesuai dengan kenyataan yang terjadi.

Imbal hasil kontrak opsi menggunakan covered call writing strategy dan protective put buying strategy dengan jatuh tempo 1 bulan, 2 bulan, dan 3 bulan mengalami hasil yang berbeda. Strategi yang lebih baik digunakan saat ini yaitu protective put buying strategy, karena memberikan keuntungan. Pada covered call writing strategy, akan menguntungkan bila harga saham bergerak netral. Pada protective put buying strategy, akan menguntungkan bila harga cenderung mengalami penurunan.

\section{DAFTAR PUSTAKA}

Adam, M. and Maurer, R., 1999. An Empirical Test of Risk-Adjusted Performance of Call Option Writing and Put Option Buying Hedge-Strategies (No. 9915). Sonderforschungsbereich 504, Universität Mannheim \& Sonderforschungsbereich 504, University of Mannheim.

Bareksa. 2015. Chart of the Day: 5 Tahun Terakhir Kinerja Kumpulan Saham Syariah Dibawah IHSG [online]. Tersedia: http://www.bareksa. com/id/text/2015/12/18/chart-of-the-day-5-tahunterakhir-kinerja-kumpulan-saham-syariah-dibawahihsg/12224/news [10 Oktober 2016)
Bursa Efek Indonesia. 2010. Derivatif. [online]. Tersedia: http://www.idx.co.id/idid/beranda/ produkdanlayanan/derivatif.aspx [7 Oktober 2016]

Bursa Efek Indonesia. 2016. Saham Blue Chip 2016 [online]. Tersedia: http://k.bei5000.com/ sahambluechip2016/ [22 November 2016]

Dash, Mihir. 2014. A Comparison of ITM and OTM Protective-Puts and Covered-Calls. Asian Journal of Finance \& Accounting Vol 6: 126-137.

Dewobroto, D., Febrian, E., Herwany, A., dan Brahmana, R. K. 2010. The Best Stock Hedging Among Option Strategies. Research Journal of Applied Sciences 5 (6): 397-403.

El-Hassan, N., Hall, T., dan Kobarg, Jan-Paul. 2004. Risk and Return of Covered Call Strategies for Balanced Funds: Australian Evidence. Retrieved fromSchool of Finance and Economics University of Technology, Sydney.

Fahmi, Irham. 2012. Pengantar Pasar Modal. Bandung: Alfabeta

Gustyana, T. T. dan Dewi, A. S. 2014. Analisis Perbandingan Keakuratan Harga Call Option Dengan Menggunakan Metode Monte Carlo Simulation dan Metode Black Scholes pada Indeks Harga Saham Gabungan (IHSG). Jurnal Manajemen Indonesia vol 14: 259-268.

Hermuningsih. 2012. Pengantar Pasar Modal Indonesia. Yogyakarta: UPP STIM YKPN

Sarmiadi dan Trinanto, Novirwan. 2007. Option Contract: Alternatif Investasi Pada Pasar Modal. Jurnal Ekonomi dan Bisnis vol 2: 182-199.

Sutedi, Adrian. 2012. Produk-produk Derivatif dan Aspek Hukumnya. Bandung: Alfabeta

Tandelilin, Eduardus. 2010. Portofolio dan Investasi Teori dan Aplikasi. Yogyakarta: Kanisius

\section{LAMPIRAN}

Tabel 1. Operasional Variabel

\begin{tabular}{|c|c|c|c|}
\hline Variabel Terukur & Konsep Variabel & Indikator & Skala \\
\hline Harga call option & $\begin{array}{l}\text { Harga yang dibayarkan oleh pembeli opsi kepada } \\
\text { penjual opsi call (Sutedi, 2012:275) }\end{array}$ & $\begin{array}{l}\text { Harga premi call option } \\
\qquad \mathrm{C}=\mathrm{S} \mathrm{N}(\mathrm{d} 1)-\mathrm{X}(\mathrm{e})^{-(\mathrm{r}) \mathrm{T}} \mathrm{N}(\mathrm{d} 2)\end{array}$ & Rasio \\
\hline Harga put option & $\begin{array}{l}\text { Harga yang dibayarkan oleh pembeli opsi kepada } \\
\text { penjual opsi put (Sutedi, 2012:275) }\end{array}$ & $\begin{array}{l}\text { Harga premi put option } \\
\qquad \mathrm{p}=\mathrm{X}(\mathrm{e})^{-(\mathrm{r}) \mathrm{T}} \mathrm{N}(-\mathrm{d} 2)-\mathrm{S} N(-\mathrm{d} 1)\end{array}$ & Rasio \\
\hline Imbal hasil & $\begin{array}{l}\text { Imbal hasil (Return) adalah keuntungan yang } \\
\text { diperoleh oleh perusahaan, individu, dan institusi } \\
\text { dari hasil kebijakan investasi yang dilakukannya } \\
\text { (Fahmi, 2012:184) }\end{array}$ & $\begin{array}{l}\text { Imbal hasil covered call } \\
\text { Imbal hasil }=\mathrm{c}+\mathrm{Ep}-\mathrm{Sp} \\
\text { Imbal hasil protective put } \\
\text { Imbal hasil }=\mathrm{Sp}-\mathrm{Ep}-\mathrm{p}\end{array}$ & Rasio \\
\hline
\end{tabular}

Tabel 5. Imbal Hasil Covered Call Writing Strategy

\begin{tabular}{cccccc}
\hline Jangka Waktu & ASII & BBCA & INDF & TLKM & HMSP \\
\hline 1 bulan & $(70,2411)$ & $(216,8787)$ & $(34,8345)$ & $(21,8793)$ & $(3.078,6570)$ \\
2 bulan & $(224,3823)$ & $(238,8037)$ & $(48,0480)$ & $(80,3377)$ & $(4.794,6901)$ \\
3 bulan & $(149,2267)$ & $(91,4630)$ & $(63,6639)$ & $(122,0591)$ & $(7.791,5612)$ \\
\hline
\end{tabular}


Tabel 6. Imbal Hasil Protective put buying strategy

\begin{tabular}{cccccc}
\hline Jangka Waktu & ASII & BBCA & INDF & TLKM & HMSP \\
\hline 1 bulan & 240,8649 & 305,5261 & 266,9787 & 40,8751 & $1.206,7973$ \\
2 bulan & 417,4412 & 392,6538 & 426,7340 & 47,3851 & 544,6065 \\
3 bulan & 435,2837 & 416,2415 & 417,6724 & 55,3932 & 93,5755 \\
\hline
\end{tabular}

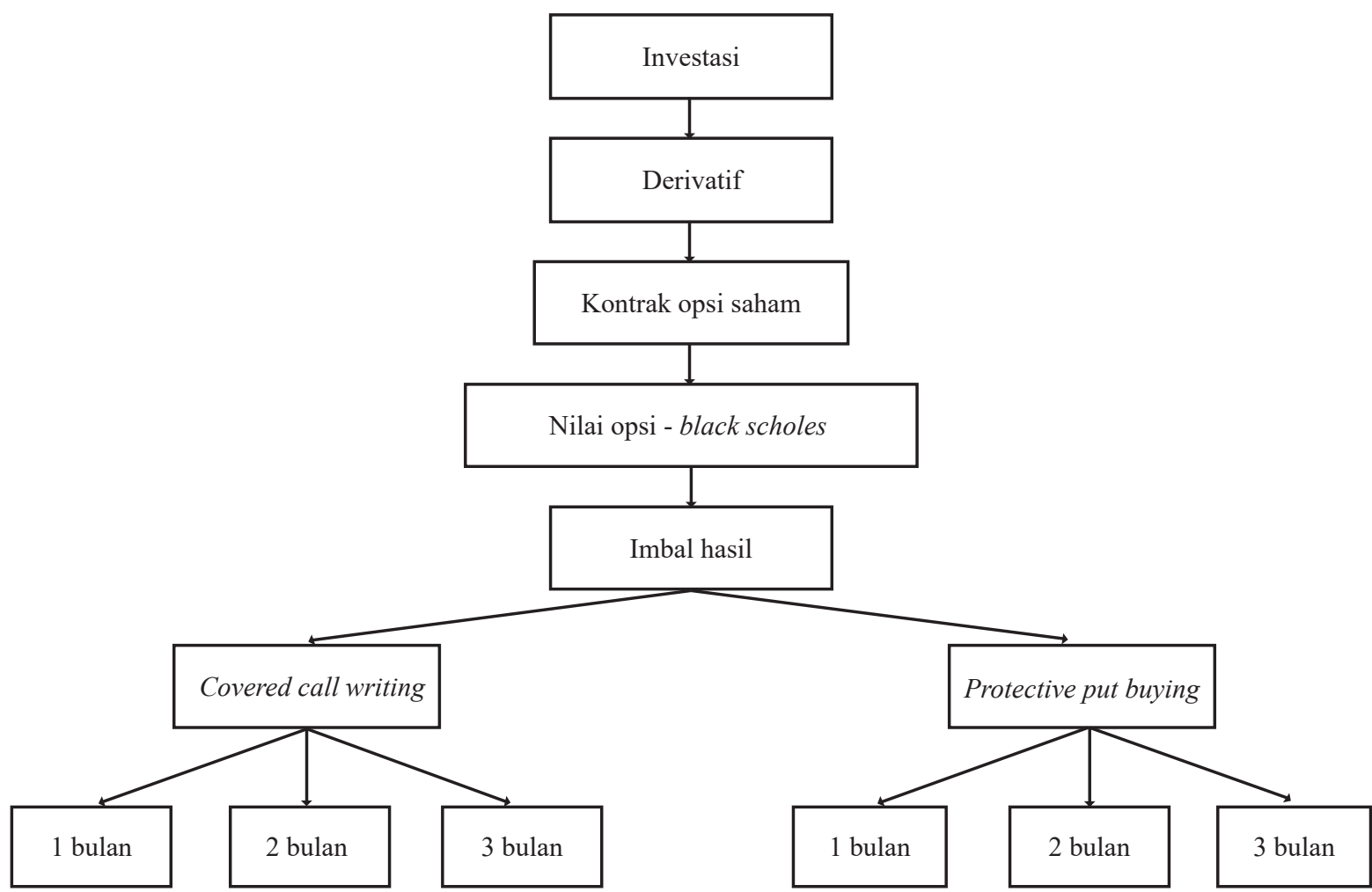

Gambar 2. Kerangka Pemikiran 